DOI: $10.19195 / 0524-4544.327 .10$

\author{
ZBIGNIEW OFIARSKI \\ ORCID: 0000-0003-1675-933X \\ Uniwersytet Szczeciński \\ zbigniew.ofiarski@usz.edu.pl
}

\title{
Marszałek województwa jako organ podatkowy
}

\begin{abstract}
Abstrakt: Marszałek województwa nie jest organem województwa — jednostki samorządu terytorialnego. Marszałek województwa pełni funkcję przewodniczącego zarządu województwa kolegialnego organu wykonawczego województwa. W prawie o daninach publicznych marszałek województwa jest organem podatkowym, a przynajmniej organem, któremu przysługują uprawnienia organu podatkowego. W rezultacie wprowadzania kolejnych opłat publicznych do polskiego systemu danin publicznych, w szczególności opłat związanych z działaniami, które negatywnie oddziałują na środowisko, rola marszałka województwa w dziedzinie ustalania i pobierania tych opłat stała się bardziej istotna. Rola marszałka województwa nie ogranicza się tylko do wymiaru i poboru opłat, ale także do wykonywania innych zadań, takich jak prowadzenie ewidencji, gromadzenie dokumentów, zawieranie porozumień, przyjmowanie sprawozdań i raportów.
\end{abstract}

Słowa kluczowe: samorząd terytorialny, marszałek województwa, organ podatkowy, opłaty, opłaty produktowe.

\section{Wprowadzenie}

W strukturach prawnych polskiego samorządu terytorialnego okresie II Rzeczypospolitej (lata 1918-1939), jak również od 1945 do 1998 roku nie funkcjonował urząd marszałka ${ }^{1}$. Dopiero w ramach drugiego etapu restytucji prawnej instytucji samorządu terytorialnego w Polsce, zapoczątkowanego od dnia 1 stycznia

1 G. Dutkiewicz, Dzieje samorządu terytorialnego w Polsce po II wojnie światowej, „Colloquium Wydziału Nauk Humanistycznych i Społecznych” 2010, R. 2, s. 193-206. 
1999 roku, utworzono samorząd województwa ${ }^{2}$. W jego strukturach marszałek województwa pełni funkcję przewodniczącego kolegialnego organu wykonawczego województwa, którym zgodnie z art. 31 ust. 1 i 2 u.s.w. jest zarząd województwa liczący pięć osób. W jego skład wchodzą marszałek województwa, a także wicemarszałek lub 2 wicemarszałków i pozostali członkowie. Pełniąc funkcję przewodniczącego zarządu województwa, marszałek wykonuje przede wszystkim obowiązki w zakresie czynności organizacyjnych, np. określa zakres zadań członków zarządu, planuje i przygotowuje posiedzenia zarządu, zwołuje posiedzenia i przewodniczy pracom zarządu, nadzoruje przebieg prac nad przygotowaniem projektów uchwał zarządu, przedkłada zarządowi projekty uchwał, podejmuje działania zapewniające prawidłowe funkcjonowanie urzędu marszałkowskiego ${ }^{3}$.

Stosownie do postanowień art. 32 ust. 1-4 u.s.w. sejmik województwa wybiera zarząd województwa, w tym marszałka województwa i nie więcej niż 2 wicemarszałków, w ciągu 3 miesięcy od dnia ogłoszenia wyników wyborów przez właściwy organ wyborczy. Wybór marszałka województwa następuje bezwzględną większością głosów ustawowego składu sejmiku, w głosowaniu tajnym. Sejmik województwa wybiera wicemarszałków oraz pozostałych członków zarządu na wniosek marszałka zwykłą większością głosów w obecności co najmniej połowy ustawowego składu sejmiku, w głosowaniu tajnym. Przed dokonaniem tych wyborów niezbędne jest objęcie mandatów przez wystarczającą liczbę radnych gwarantującą skuteczność wyboru marszałka, wicemarszałków i pozostałych członków zarządu województwa. Konieczne jest również dokonanie wyboru przewodniczącego sejmiku województwa, aby mógł on zarządzić głosowanie — najpierw nad wprowadzeniem do porządku obrad punktów dotyczących tych wyborów, a następnie przeprowadzenia tych wyborów ${ }^{4}$. Do dnia 29 maja 2001 roku marszałek był wybierany spośród radnych sejmiku województwa. W wyniku nowelizacji ustawy dokonanej z dniem 30 maja 2001 roku $^{5}$ marszałek, wicemarszałkowie i pozostali członkowie zarządu województwa mogą być wybrani spoza składu sejmiku województwa. Umożliwiono w ten sposób swobodny wybór osoby marszałka, także spoza grona radnych ${ }^{6}$.

W polskim systemie prawa podatkowego przyjęto dwie odrębne struktury organów podatkowych, tzn. państwowe organy podatkowe i samorządowe organy podatkowe. Odpowiada im podział danin publicznych na państwowe i samorządowe, które stanowią źródła dochodów własnych odpowiednio budżetu państwa

${ }^{2}$ Ustawa z dnia 5 czerwca 1998 r. o samorządzie województwa (Dz.U. z 2019 r. poz. 512), dalej: u.s.w.

3 Wyrok NSA z dnia 22 lutego 2013 r., II GSK 2134/11, Legalis nr 594132.

4 J. Korczak, Zwolywanie i obrady pierwszych sesji nowo wybranych organów stanowiacych jednostek samorzadu terytorialnego, „Nowe Zeszyty Samorządowe” 2010, nr 6, s. 100.

${ }^{5}$ Ustawa z dnia 11 kwietnia 2001 r. o zmianie ustaw: o samorządzie gminnym, o samorządzie powiatowym, o samorządzie województwa, o administracji rządowej w województwie oraz o zmianie niektórych innych ustaw (Dz.U. Nr 45, poz. 497 ze zm.).

6 J. Lemańska, Koncepcja samorządu województwa na tle porównawczym, Kraków 2006, s. 119. 
oraz budżetów jednostek samorządu terytorialnego (j.s.t.). Ustawodawca nie jest jednak konsekwentny i niektóre samorządowe źródła danin publicznych są administrowane przez państwowe organy podatkowe (dotyczy to zasilających budżety gmin podatków: od spadków i darowizn, od czynności cywilnoprawnych oraz zryczałtowanego podatku dochodowego od osób fizycznych prowadzących działalność gospodarczą ustalanego w formie karty podatkowej).

Zgodnie z art. 13 Ustawy z dnia 29 sierpnia 1997 roku Ordynacja podatkowa ${ }^{7}$ marszałek województwa jest organem podatkowym pierwszej instancji, natomiast organem odwoławczym od wydawanych przez niego decyzji podatkowych jest samorządowe kolegium odwoławcze. Do dnia 26 października 2002 roku w treści art. 13 o.p. nie wymieniano wprost marszałka województwa, ale posługiwano się ogólnym określeniem ,,przewodniczący zarządu jednostki samorządu terytorialnego". Nowelizacja art. 13 o.p. ${ }^{8}$ doprowadziła do wyczerpującego wyliczenia wszystkich samorządowych organów podatkowych pierwszej instancji, którymi są: wójt, (burmistrz, prezydent miasta), starosta albo marszałek województwa.

Celem opracowania jest analiza i ocena materiału normatywnego, orzecznictwa sądów i dorobku doktryny prawa, w szczególności prawa o daninach publicznych, dotyczących statusu prawnego marszałka województwa. W opracowaniu poddano weryfikacji hipotezę, czy rozwiązania szczegółowe przyjęte w odrębnych ustawach pozwalają na określenie statusu marszałka województwa jako organu podatkowego, czy raczej jako organu, któremu jedynie przysługują uprawnienia organu podatkowego stosownie do postanowień art. 2 o.p. Przepis art. 2 o.p. stanowi, że status taki przysługuje ,innym organom” uprawnionym do ustalania lub określania opłat, do których mają zastosowanie postanowienia działu 3 ustawy — ordynacja podatkowa pt. Zobowiązania podatkowe. W opracowaniu zastosowano metodę dogmatycznoprawną, jako metodę dominującą, oraz uzupełniająco metodę empiryczno-analityczną (w szczególności w odniesieniu do dorobku orzeczniczego sądów).

\section{Władztwo daninowe województwa - zarys problematyki}

W świetle postanowień art. 168 konstytucji RP ${ }^{9}$ wszystkie kategorie j.s.t. (gminy, powiaty i województwa) mają prawo do ustalania wysokości podatków

7 Dz.U. z 2018 r. poz. 800 ze zm., dalej: o.p.

8 Por. art. 79 pkt 1 Ustawy z dnia 20 czerwca 2002 r. o bezpośrednim wyborze wójta, burmistrza i prezydenta miasta (Dz.U. Nr 113, poz. 984 ze zm.), którą uchylono z dniem 1 sierpnia 2011 r. mocą Ustawy z dnia 5 stycznia 2011 r. Przepisy wprowadzające ustawę — Kodeks wyborczy (Dz.U. Nr 21, poz. 113 ze zm.).

9 Konstytucja Rzeczypospolitej Polskiej z dnia 2 kwietnia 1997 r. (Dz.U. Nr 78, poz. 483 ze zm.). 
i opłat lokalnych w zakresie określonym w ustawie. Struktura źródeł dochodów własnych, zwłaszcza dotycząca podatków i opłat lokalnych sprawia, że uprawnienie do wykonywania ograniczonego władztwa daninowego w obecnym stanie prawnym przysługuje $\mathrm{w}$ zasadzie tylko gminom, co wpływa niekorzystnie na wielkość dochodów własnych powiatów i województw ${ }^{10}$. Źródła dochodów j.s.t. aktualnie określa Ustawa z dnia 13 listopada 2003 roku o dochodach jednostek samorządu terytorialnego ${ }^{11}$. W katalogu źródeł dochodów własnych województw nie wymieniono żadnych podatków i opłat. W rozumieniu tej ustawy dochodami własnymi j.s.t. są udziały we wpływach z podatku dochodowego od osób fizycznych oraz z podatku dochodowego od osób prawnych, ale brak jakichkolwiek instrumentów władztwa daninowego przysługującego j.s.t. sprawia, że są to źródła dochodów własnych w znaczeniu formalnym, a nie w znaczeniu materialnym. Przyjęcie tej szczególnej „fikcji” stało się rozwiązaniem wykorzystywanym do ustalania potencjału dochodowego j.s.t., obliczania niektórych kwot subwencji ogólnej oraz nakładania obowiązku odprowadzania wpłat do budżetu w celu tworzenia części równoważącej i części regionalnej subwencji ogólnej dzielonych pomiędzy j.s.t. o niskim potencjale dochodowym. Podobne regulacje dotyczące źródeł dochodów własnych województw zawierała Ustawa z dnia 26 listopada 1998 roku o dochodach jednostek samorządu terytorialnego w latach 1999-2003 ${ }^{12}$. W związku z tym w doktrynie ocenia się, że marszałkowie województw nie są czynnymi organami podatkowymi ${ }^{13}$, a ich uprawnienia i obowiązki podatkowoprawne pozostają $\mathrm{w}$ wirtualnym wymiarze $\mathrm{e}^{14}$.

$\mathrm{W}$ art. 18 pkt 11 u.s.w. sformułowano ogólną kompetencję, według której do wyłącznej właściwości sejmiku województwa należy uchwalanie, w granicach określonych ustawami, przepisów dotyczących podatków i opłat lokalnych. Uprawnienia podatkowoprawne samorządu województwa, których wykorzystywanie wpływa na wysokość ciężaru opodatkowania, uregulowano w Ustawie $\mathrm{z}$ dnia 15 listopada 1984 roku o podatku rolnym ${ }^{15}$. Oryginalność tych postanowień polega na tym, że odnoszą się one nie do źródła dochodów własnych województwa, ale do źródła dochodów własnych gminy, ponieważ wpływy z podatku rolnego w całości zasilają budżety gmin. Skutki wykonywanego władztwa przez samorząd województwa w zakresie podatku rolnego ujawniają się zatem w budżecie gminy, a nie w budżecie województwa. Należy jednak podkreślić, że samorząd

10 A. Skoczylas, W. Piątek, Komentarz do art. 168, [w:] Konstytucja RP. Komentarz, t. 2, red. M. Safjan, L. Bosek, Warszawa 2016, s. 935.

11 Dz.U. z 2018 r. poz. 1530 ze zm., dalej: u.d.j.s.t.

12 Dz.U. Nr 150, poz. 983 ze zm.

13 K. Teszner, Komentarz do art. 13, [w:] Ordynacja podatkowa. Komentarz, red. L. Etel, Warszawa 2017, s. 154.

14 P. Smoleń, Komentarz do art. 13, [w:] Ordynacja podatkowa. Komentarz, red. H. Dzwonkowski, Warszawa 2016, s. 115.

15 Dz.U. z 2017 r. poz. 1892, dalej: u.p.r. 
województwa realizuje swoje kompetencje w zakresie podatku rolnego na wniosek zainteresowanej gminy.

Zgodnie z art. 5 ust. 2 u.p.r., sejmik województwa na wniosek rady gminy może, po zasięgnięciu opinii izby rolniczej, w szczególnych, gospodarczo uzasadnionych wypadkach zaliczyć niektóre gminy do innego okręgu podatkowego niż określony w rozporządzeniu ${ }^{16}$, ale nie może to spowodować zmniejszenia liczby hektarów przeliczeniowych dla tego województwa o więcej niż 1,5\%. Efektem takich zmian jest zmniejszenie podstawy opodatkowania i ostatecznie wysokości podatku rolnego. Ponadto w podatku rolnym stosowana jest ulga polegająca na obniżeniu kwoty obliczonego podatku dla gruntów położonych na terenach podgórskich i górskich. Według art. 13b ust. 2 u.p.r. za miejscowości położone na terenach podgórskich i górskich uważa się miejscowości, w których co najmniej 50\% użytków rolnych jest położonych powyżej $350 \mathrm{~m}$ nad poziomem morza. Wykaz tych miejscowości w danym województwie ustala sejmik województwa. Miejscowość na obszarze wiejskim (wieś, sołectwo) jest terytorialnie równoznaczna z obrębem geodezyjnym. Jednak ulga górska przysługuje nie od gospodarstw rolnych, ale od gruntów położonych na obszarze miejscowości (w obrębie geodezyjnym) na terenach górskich i podgórskich $w$ rozumieniu art. 13b ust. 2 u.p.r. O tym, czy miejscowość ma charakter górski bądź podgórski, rozstrzyga bezpośrednio sama ustawa poprzez określenie kryteriów przesadzających o tym. Inaczej mówiąc, miejscowość staje się górską lub podgórską, jeśli spełnia warunki ustawowe. Wykaz sporządzany przez sejmik województwa ma charakter deklaratoryjny ${ }^{17}$.

Wyżej wymienione kompetencje sejmiku województwa są zadaniami z zakresu administracji rządowej, o czym wprost stanowi art. $3 b$ u.p.r. Konkludując, sejmik województwa nie posiada kompetencji bezpośrednio kształtujących wysokość lokalnych danin publicznych (podatków oraz opłat) ${ }^{18}$, co jest efektem braku własnych podatkowych źródeł dochodów samorządu województwa. Władztwo daninowe sejmiku województwa można określić jako formalne i de facto wykonywane na wniosek oraz na rzecz gminy. Wykonywanie tych kompetencji, w granicach wyznaczonych przepisami ustawy o podatku rolnym, pośrednio jednak wpływa na wysokość podatku rolnego, który jest podatkiem lokalnym, a ściślej ujmując, podatkiem gminnym.

Katalog źródeł dochodów własnych województw, określony w art. 6 u.d.j.s.t., jest katalogiem otwartym, ponieważ ostatnią jego pozycją są ,inne dochody należne województwu na podstawie odrębnych przepisów". Odesłanie do odrębnych przepisów jest bardzo ogólne i nie przesądza o tym, czy „inne dochody”

16 Rozporządzenie Ministra Finansów z dnia 10 grudnia 2001 r. w sprawie zaliczenia gmin oraz miast do jednego z czterech okręgów podatkowych (Dz.U. Nr 143, poz. 1614).

17 W. Miemiec, Stosowanie ulgi górskiej w podatku rolnym, „Nowe Zeszyty Samorządowe” 2001, nr 4, s. 42.

18 M. Kotulski, Komentarz do art. 18, [w:] Komentarz do ustawy o samorządzie województwa, red. P. Chmielnicki, Warszawa 2005, s. 161-162. 
mają pochodzić ze źródeł publicznoprawnych, czy ze źródeł prywatnoprawnych. Zastosowanie przez ustawodawcę tego ogólnego zwrotu uzasadnia wniosek, że mogą to być ,inne dochody” zarówno ze źródeł publicznoprawnych, jak i prywatnoprawnych. Analizując jednak status prawny marszałka województwa jako organu podatkowego lub ,innego organu”, któremu przysługują uprawnienia organu podatkowego, należy skupić uwagę na źródłach dochodów województwa o charakterze publicznoprawnym, w stosunku do których marszałkowi województwa ustawodawca przyznał pewne kompetencje władcze. Warunki takie są zachowane zwłaszcza w odniesieniu do niektórych opłat produktowych.

\section{Status podatkowoprawny marszałka województwa w ordynacji podatkowej}

Według postanowień art. 13 o.p. marszałek województwa jest jednym z samorządowych organów podatkowych. W odróżnieniu od pozycji prawnej wójta (burmistrza, prezydenta miasta), który jest jednocześnie organem wykonawczym gminy oraz organem podatkowym, marszałek województwa (podobnie jak starosta) jest tylko przewodniczącym kolegialnego organu wykonawczego samorządu województwa (zarządu) oraz organem podatkowym w rozumieniu przepisów ustawy - ordynacja podatkowa. Według przepisów ordynacji podatkowej marszałek województwa jest uprawniony, stosownie do swojej właściwości, do wydawania interpretacji indywidualnych przepisów prawa podatkowego, a także do zmiany, uchylenia lub stwierdzenia wygaśnięcia tych interpretacji (art. 14j o.p.). Niniejsze interpretacje są wydawane na pisemny wniosek zainteresowanego - w jego indywidualnej sprawie. Zainteresowanym jest podmiot, w odniesieniu do którego wykładnia znajdujących zastosowanie w sprawie przepisów podatkowych może wpływać na prawidłowe określenie jego obowiązku podatkowego. Celem tej instytucji jest udzielenie rzetelnej i wiążącej informacji, w jaki sposób organ podatkowy interpretuje przepisy podatkowe w opisanym we wniosku stanie faktycznym, a w konsekwencji udzielenie informacji co do zasad obliczenia podatku. Interpretację przepisów prawa podatkowego wydaje się w odniesieniu do indywidualnych warunków, konkretnego stanu faktycznego, tj. sprawy, w której istotą jest ukształtowanie praw i obowiązków wnioskodawcy na gruncie określonej regulacji podatkowej. Nie chodzi więc o każdy interes prawny, lecz o interes podatkowoprawny ${ }^{19}$.

Indywidualna interpretacja podatkowa może zostać zmieniona pod pewnymi warunkami. Po pierwsze, w sytuacji gdy jej treść straciła walor prawidłowości w związku z utrwaleniem się odmiennej wykładni przepisów w orzecznictwie są-

19 Wyrok WSA w Poznaniu z dnia 27 lutego 2013 r., I SA/Po 860/12, LEX nr 1311100. 
dów (w szczególności sądów administracyjnych) oraz Trybunału Konstytucyjnego i Trybunału Sprawiedliwości. Po drugie, należy opowiedzieć się za możliwością zmiany indywidualnej interpretacji w sytuacji, gdy wydana interpretacja pominęła istniejące już utrwalone orzecznictwo. W obu tych sytuacjach rozbieżność między wydaną interpretacją a orzecznictwem sprawi, że wymieniona interpretacja nie będzie uwzględniała orzecznictwa sądów i trybunałów, czyli nie będzie spełniać wymogu ustawowego ${ }^{20}$.

Materialnoprawne regulacje ordynacji podatkowej, dotyczące marszałka województwa, odnoszą się do niektórych szczególnych sposobów wygasania zobowiązań podatkowych, np. stosowania kompensaty zobowiązania podatkowego i odszkodowania orzeczonego w decyzji wydanej przez marszałka województwa (art. 65 o.p.) albo przeniesienia własności rzeczy lub praw majątkowych na rzecz województwa na podstawie umowy zawartej na wniosek podatnika między podatnikiem i marszałkiem województwa (art. 66 o.p.).

Inne regulacje zawarte $\mathrm{w}$ ordynacji podatkowej i dotyczące marszałka województwa mają przede wszystkim charakter proceduralny i odnoszą się do: rozstrzygania przez sądy administracyjne sporów o właściwość między marszałkiem województwa a naczelnikiem urzędu skarbowego lub urzędu celno-skarbowego, a także sporów o właściwość między marszałkami województw (art. 19 o.p.); wszczęcia lub przejęcia przez Szefa Krajowej Administracji Skarbowej postępowania podatkowego na wniosek marszałka województwa w przypadkach, w których marszałek jest właściwy do ustalania lub określania podatków albo opłat (art. 119g o.p.); wyłączenia pracownika urzędu marszałkowskiego od udziału w postępowaniu w sprawach dotyczących zobowiązań podatkowych oraz innych spraw normowanych przepisami prawa podatkowego i wyznaczenia przez marszałka województwa innego pracownika do prowadzenia sprawy (art. 130 o.p.); wyłączenia marszałka województwa od załatwiania spraw dotyczących jego zobowiązań podatkowych lub osób jemu bliskich (art. 132 o.p.); przekazywania wniosków o doręczanie pism przekazywanych do władzy podatkowej innego państwa (art. 154a o.p.); udzielania przez marszałka województwa pracownikom urzędu marszałkowskiego imiennych upoważnień do przeprowadzenia kontroli podatkowej (art. 283 o.p.); zakresu obowiązku marszałka województwa i pracowników urzędu marszałkowskiego przestrzegania tajemnicy skarbowej (art. 294 o.p.).

W ordynacji podatkowej wielokrotnie stosowane jest określenie ,sprawy podatkowe", w tym również w przypadku uregulowania kompetencji marszałka województwa. W przepisach ogólnego oraz szczegółowego prawa podatkowego nie zdefiniowano pojęcia ,sprawy podatkowe”. W ujęciu leksykalnym ,sprawa” to zagadnienie, problem, kwestia ${ }^{21}$. Należy przyjąć, że wszelkie zagadnienia (problemy, kwestie) ogólnego prawa podatkowego, jak i związane ze stosowaniem przepi-

20 Wyrok WSA w Krakowie z dnia 13 lutego 2017 r., I SA/Kr 1430/16, Legalis nr 1580521.

21 Stownik synonimów polskich, red. Z. Kurzowa, Warszawa 2002, s. 373. 
sów regulujących dany podatek lub opłatę publiczną będą zawierały się w zakresie właściwości samorządowego organu podatkowego, tzn. w omawianej sytuacji marszałka województwa - z wyłączeniem tych, które ustawodawca przekazał do wyłącznej właściwości sejmiku województwa (np. omówione wyżej uprawnienia sejmiku województwa dotyczące niektórych elementów prawnej konstrukcji podatku rolnego).

Uregulowane w ogólnym prawie podatkowym kompetencje marszałka województwa mogą być wykorzystywane tylko w przypadku, gdy przepisy szczegółowego prawa daninowego upoważniają marszałka do administrowania określonym źródłem dochodów publicznoprawnych. Nie jest przy tym konieczne, aby było to źródło dochodów własnych samorządu województwa. Marszałek województwa może również administrować źródłem dochodów budżetu państwa lub państwowego funduszu celowego, realizując de facto zadanie zlecone z zakresu administracji rządowej i w związku z tym wykonuje uprawnienia organu podatkowego albo „innego organu”, któremu przysługują uprawnienia organu podatkowego. W tym kontekście należy przedstawić istotne funkcje wykonywane przez marszałka województwa w zakresie wymiaru i poboru niektórych opłat produktowych.

\section{Kompetencje podatkowoprawne marszałka województwa w odniesieniu do niektórych opłat produktowych}

Ustawodawca ustala ważne zadania marszałka województwa w procedurze wymiaru opłat produktowych. Status prawny tych opłat różnie jest oceniany w doktrynie prawa daninowego. Dominuje jednak pogląd, według którego są to obciążenia o charakterze publicznoprawnym. Pomimo stosowania ustawowego określenia „opłata” niektórzy autorzy uznają je za szczególny rodzaj podatków związanych z ochroną środowiska (tzw. podatki środowiskowe) ${ }^{22}$. Dostrzegane są również inne ważne cechy opłat produktowych pozwalające na ich umieszczanie pomiędzy podatkami i typowymi opłatami publicznymi (np. opłatami skarbowymi). Akcentuje się, że opłaty produktowe są ekwiwalentne i pełnią ważne funkcje pozafiskalne, np. bodźcową, prewencyjną oraz dystrybucyjną. Mogą być wykorzystywane do realizacji jednej z głównych zasad prawa ochrony środowiska, według której „,zanieczyszczający płaci”23. O publicznoprawnym charakterze

22 D. Mączyński, Opłata produktowa - podatek środowiskowy, „Monitor Podatkowy” 2002, nr 4, s. $18-22$.

23 B. Draniewicz, Opłata produktowa, Warszawa 2009, s. 262-264; B. Draniewicz, Spór o charakter prawny opłat produktowych, „Przegląd Prawa Publicznego” 2008, nr 12, s. 24-37. 
opłat produktowych przesądza powtórzony w kilku odrębnych ustawach ${ }^{24}$ nakaz odpowiedniego stosowania do nich przepisów działu 3 ustawy - ordynacja podatkowa pt. Zobowiąania podatkowe. Znajduje to odzwierciedlenie w złożonej strukturze kompetencji marszałka województwa dotyczących opłat produktowych.

W polskim ustawodawstwie nie sformułowano jednej, uniwersalnej definicji pojęcia „opłata produktowa”. Określenie to jest stosowane w kilku ustawach regulujących gospodarowanie różnymi produktami uciążliwymi dla środowiska. Wymiar i pobór tych opłat związany jest z nieosiągnięciem wymaganego poziomu odzysku lub recyklingu określonych przedmiotów mających status odpadów lub produktów niebezpiecznych dla środowiska. Opłaty produktowe nie stanowią jednorodnej kategorii opłat. Poszczególne opłaty produktowe różnią się między sobą zakresem przedmiotowym i podmiotowym, podstawą i sposobem wymiaru, wysokością stawek, przeznaczeniem uzyskanych wpływów, podmiotami administrującymi źródłami poszczególnych opłat. Można przy tym wyodrębnić typowe opłaty produktowe (sensu stricto) oraz pozostałe opłaty ściśle związane z procedurą wymiaru i poboru opłat produktowych (sensu largo). Do pierwszej grupy zaliczane są opłaty produktowe (w tym dodatkowe opłaty produktowe) wymierzane i pobierane na podstawie przepisów ustaw regulujących tryb postępowania z różnymi rodzajami odpadów lub innymi produktami, które mają niekorzystny wpływ na środowisko. W drugiej grupie mieszczą się opłaty pobierane cyklicznie (opłaty roczne) oraz opłaty związane z określonymi zdarzeniami mającymi jedynie pośredni związek z gospodarowaniem odpadami (opłaty rejestrowe, depozytowe oraz przeznaczone na finansowanie publicznych kampanii edukacyjnych) ${ }^{25}$. W każdym z tych przypadków określone zadania i funkcje wykonuje marszałek województwa.

Wśród opłat produktowych istotne znaczenie mają opłaty pobierane w związ$\mathrm{ku}$ z gospodarowaniem niektórymi odpadami. Wymiarem i poborem tych opłat zajmuje się marszałek województwa. Zgodnie z przepisami ustawy o obowiązkach przedsiębiorców w zakresie gospodarowania niektórymi odpadami oraz o opłacie produktowej ustala się i pobiera opłatę produktową w celu: zapobiegania powstawaniu odpadów powstałych z produktów, ograniczenia ich negatywnego oddziaływania na środowisko oraz zapewnienia wysokiego poziomu odzysku i recyklingu odpadów powstałych z produktów. Obowiązek wniesienia opłaty produktowej

${ }^{24}$ Np. w ustawach: z dnia 24 kwietnia 2009 r. o bateriach i akumulatorach (Dz.U. z 2019 r. poz. 521); Ustawie z dnia 11 maja 2001 r. o obowiązkach przedsiębiorców w zakresie gospodarowania niektórymi odpadami oraz o opłacie produktowej (Dz.U. z 2018 r. poz. 1932); z dnia 11 września 2015 r. o zużytym sprzęcie elektrycznym i elektronicznym (Dz.U. z 2018 r. poz. 1466 ze zm.); z dnia 13 czerwca 2013 r. o gospodarce opakowaniami i odpadami opakowaniowymi (Dz.U. z 2019 r. poz. 542); z dnia 20 stycznia 2005 r. o recyklingu pojazdów wycofanych z eksploatacji (Dz.U. z 2018 r. poz. 578 ze zm.).

25 M. Ofiarska, Udziały we wpływach z opłat produktowych jako źródto dochodów samorzadu województwa, „Prace Naukowe UE we Wrocławiu” 2015, nr 404, s. 193. 
przez przedsiębiorcę powstaje w przypadku nieosiągnięcia przez niego wymaganego poziomu odzysku i recyklingu. Rozliczenie wykonania tego obowiązku następuje na koniec roku kalendarzowego. Opłaty produktowe przedsiębiorca oblicza samodzielnie, zgodnie z ustawowo określonymi zasadami, oddzielnie dla każdego rodzaju produktu w przypadku nieosiągnięcia wymaganego poziomu odzysku lub recyklingu. Roczne, procentowe poziomy odzysku i recyklingu, określane przez ministra właściwego do spraw środowiska, w piśmiennictwie uznawane są za odpowiednik podatkowego minimum sensu largo, którego przekroczenie powoduje przyjęcie za podstawę obliczenia opłaty tylko nadwyżki podstawy ponad minimum określone normatywnie ${ }^{26}$. Nie powstaje obowiązek zapłaty opłaty produktowej, jeżeli łączna roczna jej wysokość dla wszystkich produktów nie przekracza $100 \mathrm{zł}$.

Zgodnie z art. 16 i art. 17 cytowanej wyżej ustawy obliczoną na koniec roku kalendarzowego opłatę produktową przedsiębiorca powinien wpłacić na wyodrębniony rachunek bankowy urzędu marszałkowskiego w terminie do dnia 31 marca roku kalendarzowego następnego roku. Zobowiązanie z tytułu opłaty produktowej dotyczy zawsze konkretnego podmiotu zobowiązanego oraz przedmiotu zobowiązania (określonej należności za konkretny okres). A zatem na pojęcie „zobowiązania z tytułu opłaty produktowej" składa się zarówno aspekt przedmiotowy, jak i podmiotowy ${ }^{27}$. Do zakresu obowiązków marszałka województwa należy monitorowanie sposobu i terminu wykonywania tego zobowiązania. W razie stwierdzenia, że podmiot zobowiązany nie wniósł opłaty produktowej lub uiścił ją w kwocie niższej od należnej, marszałek województwa wydaje decyzję określającą wysokość zaległości z tego tytułu. Decyzja określająca wysokość zaległości w opłacie produktowej ma charakter deklaratoryjny, a nie konstytutywny ${ }^{28}$. W przypadku niewykonania tej decyzji marszałek województwa ustala w drodze decyzji dodatkową opłatę produktową w wysokości $50 \%$ kwoty niewpłaconej opłaty produktowej. Termin płatności opłaty produktowej i dodatkowej opłaty produktowej wynosi 14 dni od dnia, w którym decyzja ustalająca wysokość opłaty stała się ostateczna.

Status prawny marszałka województwa w zakresie opłat produktowych wymierzanych na podstawie ustawy o obowiązkach przedsiębiorców w zakresie gospodarowania niektórymi odpadami oraz o opłacie produktowej określa art. 19 tej ustawy. Nie został on nazwany organem podatkowym, lecz podmiotem, któremu przysługują uprawnienia organu podatkowego, natomiast do opłat produktowych $\mathrm{w}$ zakresie nieuregulowanym $\mathrm{w}$ tej ustawie stosuje się odpowiednio przepisy działu 3 ustawy — ordynacja podatkowa. Marszałek województwa, jako organ właściwy w sprawach opłaty produktowej, dokonuje kontroli prawidłowości samoobliczenia wysokości opłaty produktowej przez podmiot zobowiązany.

26 W. Fill, Determinanty oraz kształt wspótczesnego systemu należności związanych z odpadami, „Finanse Komunalne” 2012, nr 11, s. 53.

27 Wyrok NSA z dnia 26 września 2017 r., II OSK 118/16, Legalis nr 1690636.

28 Wyrok WSA w Gliwicach z dnia 16 października 2014 r., I SA/GI 306/14, LEX nr 1647219. 
W wyniku tej kontroli marszałek województwa dokonuje określenia opłaty — przy czym „wymiar kontrolny” przybiera formę decyzji deklaratoryjnej, pomimo że jednocześnie określane są w niej odsetki za zwłokę naliczane od następnego dnia po upływie terminu płatności ${ }^{29}$.

Właściwość miejscową marszałka województwa wyznacza siedziba albo miejsce zamieszkania podmiotu zobowiązanego do zapłaty opłaty produktowej, a w przypadku braku siedziby albo miejsca zamieszkania na terytorium Rzeczypospolitej Polskiej właściwym w sprawie tej opłaty jest Marszałek Województwa Mazowieckiego. Stosownie do tej reguły ustala się również urząd marszałkowski prowadzący odrębny rachunek bankowy w celu gromadzenia i odpowiedniego przekazywania wpływów z opłaty produktowej. Jest to określenie zawarte w art. 27 ust. 1 cy towanej ustawy, które należy uznać za nieprecyzyjne, ponieważ rachunek bankowy nie jest prowadzony przez urząd marszałkowski, lecz przez bank dla urzędu marszałkowskiego będącego - w rozumieniu Ustawy z dnia 29 sierpnia 1997 roku Prawo bankowe ${ }^{30}$ — posiadaczem tego rachunku. Wpływy z tytułu opłaty produktowej oraz dodatkowej opłaty produktowej, powiększone o przychody z oprocentowania rachunków bankowych i pomniejszone o dochody urzędów marszałkowskich, są przekazywane w terminie 30 dni po upływie każdego kwartału na rachunek bankowy Narodowego Funduszu Ochrony Środowiska i Gospodarki Wodnej. Wpływy z omawianych opłat produktowych w wysokości $2 \%$ stanowią dochody budżetu samorządowego województwa z przeznaczeniem na koszty egzekucji należności z tytułu opłat produktowych i obsługę administracyjną systemu opłat produktowych.

Kolejnymi odmianami opłat produktowych są opłaty wymierzane z tytułu gospodarowania opakowaniami (opłaty produktowe oraz opłaty recyklingowe) stosownie do przepisów ustawy o gospodarce opakowaniami i odpadami opakowaniowymi. Zostały one wprowadzone w celu zmniejszenia ilości i szkodliwości dla środowiska materiałów i substancji zawartych w opakowaniach i odpadach opakowaniowych oraz w celu zmniejszenia ilości i szkodliwości dla środowiska opakowań i odpadów opakowaniowych na etapie procesu produkcyjnego, wprowadzania do obrotu, dystrybucji i przetwarzania, w szczególności przez wytwarzanie czystych produktów i stosowanie czystych technologii.

Wprowadzający opakowania do obrotu, będący przedsiębiorcą, jest obowiązany ograniczać ilość i negatywne oddziaływanie na środowisko substancji stosowanych do wytwarzania opakowań oraz wytwarzanych odpadów opakowaniowych, a także ograniczać ilość i negatywne oddziaływanie na środowisko substancji stosowanych do wytwarzania opakowań oraz wytwarzanych odpadów opakowaniowych. Jego obowiązkiem jest wprowadzanie do obrotu opakowań projektowa-

29 B. Draniewicz, Glosa do wyroku WSA z dnia 26 kwietnia 2013 r., IV SA/Wa 2499/12, „Prawo i Środowisko" 2013, nr 4, s. 132.

30 Dz.U. z 2018 r. poz. 2187 ze zm. 
nych i wykonanych w sposób umożliwiający ich wielokrotne użycie i późniejszy recykling albo przynajmniej ich recykling, jeżeli nie jest możliwe ich wielokrotne użycie, albo inną formę ich odzysku, jeżeli nie jest możliwy recykling.

Obowiązek wnoszenia opłaty produktowej powstaje w sytuacji, w której wprowadzający produkty w opakowaniach nie wykona ustawowych obowiązków w zakresie recyklingu lub odzysku opakowań. Podstawę obliczenia opłaty produktowej stanowi masa w kilogramach opakowań danego rodzaju, w których produkty zostały wprowadzone do obrotu. W ustawie ustalono maksymalną kwotową stawkę opłaty produktowej, natomiast minister właściwy do spraw środowiska w porozumieniu z ministrem właściwym do spraw finansów publicznych oraz ministrem właściwym do spraw gospodarki określa, w drodze rozporządzenia ${ }^{31}$, szczegółowe stawki opłat produktowych dla poszczególnych rodzajów opakowań, kierując się negatywnym oddziaływaniem na środowisko odpadów opakowaniowych powstałych z tych opakowań, kosztami ich zagospodarowania. Powinien jednocześnie wprowadzać pozytywne bodźce do poddawania odpadów opakowaniowych odzyskowi i recyklingowi. Opłaty produktowe powinny przede wszystkim prowadzić do racjonalizacji gospodarki opakowaniami i odpadami opakowaniowymi ${ }^{32}$.

Samoobliczenia opłaty produktowej na koniec roku kalendarzowego dokonuje podmiot zobowiązany do jej zapłaty. Powinien wnieść obliczoną opłatę na odrębny rachunek bankowy prowadzony przez marszałka województwa do dnia 15 marca roku następującego po roku kalendarzowym, którego opłata dotyczy. Jeżeli podmiot zobowiązany nie wniesie opłaty produktowej albo wpłaci kwotę niższą od należnej, to marszałek województwa ustala, w drodze decyzji, wysokość zaległości z tytułu opłaty produktowej. W przypadku niewykonania tej decyzji marszałek województwa ustala, w drodze decyzji, dodatkową opłatę produktową w wysokości odpowiadającej 50\% kwoty niewniesionej opłaty produktowej. Termin uiszczenia tych opłat wynosi 14 dni od dnia, w którym decyzja ustalająca ich wysokość stała się ostateczna.

Udział w wysokości 10\% wpływów z tych opłat jest dochodem budżetu województwa i powinien być przeznaczony na pokrycie kosztów egzekucji należności z tytułu tych opłat oraz obsługi administracyjnej ich systemu. Pozostałe wpływy marszałek województwa przekazuje, w terminie 30 dni po upływie każdego kwartału, na rachunek bankowy Narodowego Funduszu Ochrony Środowiska i Gospodarki Wodnej. Zgodnie z art. 40 ustawy o gospodarce opakowaniami i odpadami opakowaniowymi w sprawach dotyczących opłat produktowych oraz dodatkowych opłat produktowych stosuje się odpowiednio przepisy działu 3 ustawy — ordynacja podatkowa, natomiast uprawnienia organu podatkowego przysługują marszałkowi województwa. Zastosowano w tym przypadku analogiczne rozwiązanie

31 Rozporządzenie Ministra Środowiska z dnia 16 grudnia 2014 r. w sprawie stawek opłat produktowych dla poszczególnych rodzajów opakowań (Dz.U. z 2014 r. poz. 1972).

32 U. Szymańska, Z. Zacher, Opłata produktowa $w$ ochronie środowiska przed odpadami opakowaniowymi, „Ochrona Środowiska. Przegląd” 2004, nr 4, s. 41-51. 
jak w odniesieniu do opłat produktowych pobieranych z tytułu gospodarowania niektórymi odpadami.

Do kategorii opłat produktowych zalicza się także opłaty wymierzane od zużytego sprzętu elektrycznego i elektronicznego oraz baterii przenośnych i akumulatorów. Są one uregulowane w ustawie o zużytym sprzęcie elektrycznym i elektronicznym. Stanowią instrument służący ochronie środowiska i zdrowia ludzi przez zapobieganie niekorzystnym skutkom oddziaływania zużytego sprzętu elektrycznego i elektronicznego na środowisko. Podmiotem zobowiązanym do wnoszenia takich opłat jest wprowadzający sprzęt elektryczny lub elektroniczny (mający siedzibę na terytorium Rzeczypospolitej Polskiej), który nie wykonał obowiązku osiągnięcia minimalnego rocznego poziomu zbierania zużytego sprzętu, poziomu odzysku lub poziomu przygotowania do ponownego użycia i recyklingu zużytego sprzętu. Opłata produktowa jest obliczana oddzielnie dla każdej grupy sprzętu.

Elementy konstrukcyjne opłaty produktowej określono w wyżej wymienionej ustawie. Podstawę obliczenia opłaty stanowi masa w kilogramach zużytego sprzętu. Należna opłata produktowa to iloczyn stawki opłaty produktowej i różnicy pomiędzy odpowiednio wymaganym a osiągniętym minimalnym rocznym poziomem zbierania zużytego sprzętu, poziomem odzysku oraz poziomem przygotowania do ponownego użycia i recyklingu zużytego sprzętu. Maksymalne stawki opłat dla poszczególnych grup sprzętu ustalono w ustawie, natomiast minister właściwy do spraw środowiska w porozumieniu z ministrem właściwym do spraw finansów publicznych określił, w drodze rozporządzenia ${ }^{33}$, szczegółowe stawki opłaty produktowej, kierując się kosztami zbierania, przygotowania do ponownego użycia i recyklingu oraz innych niż recykling procesów odzysku zużytego sprzętu dla poszczególnych grup sprzętu.

Podmiot zobowiązany dokonuje samoobliczenia opłaty produktowej na koniec roku kalendarzowego i wpłaca bez wezwania na odrębny rachunek bankowy właściwego urzędu marszałkowskiego w terminie do dnia 15 marca roku następującego po roku kalendarzowym, którego opłata dotyczy. Nie wnosi się opłaty produktowej za daną grupę sprzętu, jeżeli nie przekracza ona kwoty 50 zł. Wpływy z tytułu opłaty produktowej oraz dodatkowej opłaty produktowej, powiększone o wysokość dochodów z oprocentowania rachunków bankowych i pomniejszone o $10 \%$ wpływów stanowiących dochód budżetu samorządu województwa, marszałek województwa przekazuje, w terminie 30 dni po upływie każdego kwartału, na rachunek bankowy Narodowego Funduszu Ochrony Środowiska i Gospodarki Wodnej.

Wprowadzający sprzęt oraz organizacja odzysku sprzętu elektrycznego i elektronicznego mają obowiązek prowadzenia publicznych kampanii edukacyjnych w stosunku do sprzętu, który został wprowadzony do obrotu. W związku z tym

33 Rozporządzenie Ministra Środowiska z dnia 14 czerwca 2018 r. w sprawie szczegółowych stawek opłaty produktowej dla grup sprzętu (Dz.U. z 2018 r. poz. 1194). 
wprowadzający sprzęt przeznacza na publiczne kampanie edukacyjne lub wnosi na odrębny rachunek bankowy właściwego urzędu marszałkowskiego nie mniej niż $0,1 \%$ przychodów netto z tytułu wprowadzania do obrotu sprzętu osiągniętych w poprzednim roku kalendarzowym. Organizacja odzysku sprzętu elektrycznego i elektronicznego, która rozpoczyna działalność w danym roku kalendarzowym, przeznacza na publiczne kampanie edukacyjne nie mniej niż 5\% przychodów netto uzyskanych w tym roku kalendarzowym albo taką kwotę wpłaca na wyodrębniony rachunek bankowy urzędu marszałkowskiego. Jeżeli wyżej wymienione podmioty nie wykonają swoich obowiązków w zakresie prowadzenia publicznej kampanii edukacyjnej, to marszałek województwa określa, w drodze decyzji, wysokość zobowiązania z tytułu środków przeznaczonych na publiczną kampanię edukacyjną. Do środków wpłacanych na wyodrębniony rachunek bankowy właściwego urzędu marszałkowskiego stosuje się odpowiednio przepisy działu 3 ustawy — ordynacja podatkowa, natomiast uprawnienia organu podatkowego przysługują marszałkowi województwa.

Jeżeli podmiot zobowiązany nie wpłaci należnej kwoty opłaty produktowej na wyodrębniony rachunek bankowy urzędu marszałkowskiego albo wpłaci kwotę niższą od należnej, to marszałek województwa określa, w drodze decyzji, wysokość zobowiązania $\mathrm{z}$ tytułu opłaty produktowej. W przypadku niewykonania tej decyzji marszałek województwa ustala, w drodze decyzji, dodatkową opłatę produktową w wysokości odpowiadającej $50 \%$ kwoty niewniesionej opłaty produktowej. Termin uiszczenia opłaty dodatkowej wynosi 14 dni od dnia, w którym decyzja ustalająca jej wysokość stała się ostateczna. Opłatę dodatkową należy wnieść na odrębny rachunek bankowy właściwego urzędu marszałkowskiego. Do należności z tytułu opłat produktowych oraz dodatkowych opłat produktowych również stosuje się odpowiednio przepisy działu 3 ustawy — ordynacja podatkowa, a uprawnienia organu podatkowego przysługują marszałkowi województwa.

Marszałek województwa spełnia analogiczne funkcje w odniesieniu do opłat produktowych oraz dodatkowych opłat wymierzanych w przypadku nieosiągnięcia przez wprowadzającego baterie przenośne lub akumulatory przenośne ustalonych poziomów ich zbierania ${ }^{34}$. W przepisach ustawy o bateriach i akumulatorach uregulowano również tryb wnoszenia opłat depozytowych i zasady postępowania w przypadku ich nieodebrania przez uprawnione podmioty.

Szczególnym rodzajem opłat produktowych są opłaty depozytowe unormowane w art. 53-56 ustawy o bateriach i akumulatorach. Ich wymiaru dokonuje się w związku z procesami gospodarowania sprzętem negatywnie oddziałującym na środowisko. Sprzedawca detaliczny baterii samochodowych kwasowo-ołowiowych lub akumulatorów samochodowych kwasowo-ołowiowych jest obowiązany do pobrania od kupującego niebędącego przedsiębiorcą opłaty depozytowej oraz do potwierdzenia jej pobrania, jeżeli przy sprzedaży tych baterii lub akumu-

34 Ustawa z dnia 24 kwietnia 2009 r. o bateriach i akumulatorach (Dz.U. z 2019 r. poz. 521). 
latorów kupujący nie przekazał mu zużytych baterii lub zużytych akumulatorów. Stawka tej opłaty wynosi 30 zł od każdej baterii lub akumulatora. Sprzedawca detaliczny jest obowiązany, w terminie 30 dni od dnia pobrania opłaty depozytowej, do przyjęcia zużytych baterii samochodowych kwasowo-ołowiowych lub zużytych akumulatorów samochodowych kwasowo-ołowiowych oraz do zwrotu pobranej opłaty depozytowej i potwierdzenia jej zwrotu. Jeżeli zwrot pobranej opłaty depozytowej przez sprzedawcę detalicznego nie jest możliwy z powodu jego likwidacji, upadłości albo przerwy w wykonywanej działalności gospodarczej, wprowadzający baterie samochodowe kwasowo-ołowiowe lub akumulatory samochodowe kwasowo-ołowiowe jest obowiązany, w terminie 45 dni od dnia ich sprzedaży, do przyjęcia od kupującego zużytych baterii lub zużytych akumulatorów wprowadzonych przez niego do obrotu oraz do zwrotu pobranej opłaty depozytowej i potwierdzenia jej zwrotu w zorganizowanych przez niego punktach zbierania tych zużytych baterii lub zużytych akumulatorów.

Sprzedawca detaliczny przekazuje nieodebraną opłatę depozytową na odrębny rachunek bankowy urzędu marszałkowskiego właściwego ze względu na siedzibę tego sprzedawcy, w terminie do dnia 15 marca roku następującego po roku, w którym nastąpiło pobranie opłaty. Do opłat depozytowych stosuje się odpowiednio przepisy działu 3 ustawy — ordynacja podatkowa, natomiast uprawnienia organu podatkowego przysługują marszałkowi województwa. Wpływy z tytułu opłat (produktowej, dodatkowej opłaty produktowej, opłaty na publiczne kampanie edukacyjne oraz nieodebranej opłaty depozytowej) pobierane na podstawie ustawy o bateriach i akumulatorach, powiększone o przychody z oprocentowania rachunków bankowych i pomniejszone o dochody budżetu samorządu województwa (wynoszące 5\% wpływów z tych opłat), marszałek województwa przekazuje w terminie 30 dni po upływie każdego kwartału na rachunek bankowy Narodowego Funduszu Ochrony Środowiska i Gospodarki Wodnej.

\section{Podsumowanie}

Marszałek województwa nie jest organem podatkowym w rozumieniu art. 13 o.p. (tzn. zaliczanym do kategorii samorządowych organów podatkowych) w odniesieniu do opłat produktowych, a także innych opłat pobieranych na podstawie ustaw regulujących zasady postępowania z różnymi odpadami lub innymi przedmiotami negatywnie wpływającymi na środowisko. Jego status prawny należy oceniać poprzez pryzmat regulacji zawartej w art. 2 § 2 i 3 o.p., według której jeżeli odrębne przepisy nie stanowią inaczej, to przepisy działu 3 ustawy — ordynacja podatkowa stosuje się również do opłat, do których ustalenia lub określenia uprawnione są organy inne niż organy podatkowe. Innym organom w takich przypadkach przysługują uprawnienia organów podatkowych. Konkludując, 
możliwe są takie sytuacje, w których ,inny organ” jest uprawniony do ustalania lub określania opłat publicznoprawnych ${ }^{35}$. $Z$ treści cytowanego art. 2 \& 2 i 3 o.p. jednoznacznie wynika, że ,inne organy” ograniczono do ustalania lub określania opłat. Na podstawie tego przepisu ,inne organy” nie mogą ustalać lub określać należności publicznoprawnych, które nie mają statusu opłaty (np. niepodatkowych należności budżetowych, kar pieniężnych) ${ }^{36}$.

W odniesieniu do administracyjnych kar pieniężnych ustawodawca nie jest jednak konsekwentny. Można wskazać na brak spójności między regulacjami zawartymi w art. $2 \S 2$ i 3 o.p. oraz art. 281 Ustawy z dnia 27 kwietnia 2001 roku Prawo ochrony środowiska ${ }^{37}$. Zgodnie $\mathrm{z}$ art. 281 tej ustawy do ponoszenia opłat za korzystanie ze środowiska oraz administracyjnych kar pieniężnych stosuje się odpowiednio przepisy działu 3 ustawy — ordynacja podatkowa, natomiast uprawnienia organów podatkowych przysługują marszałkowi województwa albo wojewódzkiemu inspektorowi ochrony środowiska. Wyłączono tylko stosowanie wobec administracyjnych kar pieniężnych przepisów ordynacji podatkowej dotyczących terminu płatności należności, odroczenia tego terminu, zaniechania ustalenia zobowiązania, zaniechania poboru należności oraz umarzania zaległych zobowiązań i odsetek za zwłokę. W pozostałym zakresie do takich kar są stosowane przepisy ustawy - ordynacja podatkowa ${ }^{38}$.

$\mathrm{Z}$ poddanych analizie uprawnień marszałka województwa dotyczących wymiaru oraz poboru opłat produktowych, które są szczególnego rodzaju daninami publicznymi, wynika, że w tym zakresie nie jest on organem podatkowym, lecz „innym organem”, któremu przysługują uprawnienia organu podatkowego. Jego kompetencje w zasadzie pozbawione są elementu władztwa, ponieważ wszystkie elementy prawnej konstrukcji opłat produktowych uregulowano wyczerpująco w przepisach ustawowych. Nie pozostawiono również marszałkowi województwa tzw. luzu decyzyjnego w odniesieniu do wymiaru dodatkowych opłat produktowych mających charakter sankcji (w każdym przypadku musi być ustalona w wysokości 50\% niewniesionej opłaty produktowej). Jedynie w przypadku stosowania ulg w zapłacie takich opłat (rozkładanie na raty, odraczanie terminu zapłaty lub umarzanie zaległości), uregulowanych w dziale 3 ustawy — ordynacja podatkowa, marszałkowi województwa pozostawiono określony zakres luzu decyzyjnego, którego granice są wyznaczone przesłankami ustawowymi stosowania tych ulg (interes publiczny lub uzasadniony ważny interes podmiotu zobowiązanego).

35 T. Nowak, H. Dzwonkowski, Komentarz do art. 2, [w:] Ordynacja podatkowa. Komentarz, red. H. Dzwonkowski, Warszawa 2016, s. 16.

36 M. Popławski, Komentarz do art. 2, [w:] Ordynacja podatkowa. Komentarz, red. L. Etel, Warszawa 2017, s. 45.

37 Dz.U. z 2018 r. poz. 799 ze zm.

38 W. Fill, Charakter prawny administracyjnych kar pieniężnych (na tle prawa ochrony środowiska), „Państwo i Prawo” 2009, z. 6, s. 65. 
Uprawnienia marszałka województwa, jako ,innego organu”, któremu przysługują uprawnienia organu podatkowego, łączone są nie tylko z wymiarem i poborem tych danin publicznych. Mają one zdecydowanie szerszy zakres przedmiotowy, ponieważ marszałek województwa przyjmuje zabezpieczenia finansowe od podmiotów zobowiązanych i prowadzi ewidencję ich rozliczeń, gromadzi kopie zaświadczeń wydawanych przez odpowiednie instytucje podmiotom gospodarującym odpadami i innymi niebezpiecznymi produktami, gromadzi kopie sprawozdań $\mathrm{z}$ audytów przeprowadzanych w ww. podmiotach, zawiera porozumienia z organizacjami samorządu gospodarczego reprezentującymi podmioty gospodarujące odpadami oraz przyjmuje raporty z realizacji takich porozumień. Konkludując, jako ,inny organ” posiadający uprawnienia organu podatkowego, marszałek województwa dokonuje kompleksowej obsługi określonej daniny publicznej. Obsługa taka obejmuje czynności wymiaru i poboru daniny publicznej oraz czynności dodatkowe w postaci prowadzenia ewidencji, gromadzenia dokumentów, zawierania porozumień, przyjmowania sprawozdań i raportów.

\section{Bibliografia}

Draniewicz B., Glosa do wyroku WSA z dnia 26 kwietnia 2013 r., IV SA/Wa 2499/12, „Prawo i Środowisko" 2013, nr 4.

Draniewicz B., Opłata produktowa, Warszawa 2009.

Draniewicz B., Spór o charakter prawny opłat produktowych, „Przegląd Prawa Publicznego” 2008, nr 12.

Dutkiewicz G., Dzieje samorzadu terytorialnego w Polsce po II wojnie światowej, „Colloquium Wydziału Nauk Humanistycznych i Społecznych" 2010, R. 2.

Fill W., Charakter prawny administracyjnych kar pieniężnych (na tle prawa ochrony środowiska), „Państwo i Prawo” 2009, z. 6.

Fill W., Determinanty oraz kształt współczesnego systemu należności związanych z odpadami, „Finanse Komunalne" 2012, nr 11.

Korczak J., Zwoływanie i obrady pierwszych sesji nowo wybranych organów stanowiacych jednostek samorzadu terytorialnego, „Nowe Zeszyty Samorządowe” 2010, nr 6.

Kotulski M., Komentarz do art. 18, [w:] Komentarz do ustawy o samorządzie województwa, red. P. Chmielnicki, Warszawa 2005.

Lemańska J., Koncepcja samorządu województwa na tle porównawczym, Kraków 2006.

Mączyński D., Opłata produktowa - podatek środowiskowy, „Monitor Podatkowy” 2002, nr 4.

Miemiec W., Stosowanie ulgi górskiej w podatku rolnym, „Nowe Zeszyty Samorządowe” 2001, nr 4.

Nowak T., Dzwonkowski H., Komentarz do art. 2, [w:] Ordynacja podatkowa. Komentarz, red. H. Dzwonkowski, Warszawa 2016.

Ofiarska M., Udziały we wpływach z opłat produktowych jako źródło dochodów samorządu województwa, „Prace Naukowe UE we Wrocławiu” 2015, nr 404.

Popławski M., Komentarz do art. 2, [w:] Ordynacja podatkowa. Komentarz, red. L. Etel, Warszawa 2017.

Skoczylas A., Piątek W., Komentarz do art. 168, [w:] Konstytucja RP. Komentarz, t. 2, red. M. Safjan, L. Bosek, Warszawa 2016. 
Słownik synonimów polskich, red. Z. Kurzowa, Warszawa 2002.

Smoleń P., Komentarz do art. 13, [w:] Ordynacja podatkowa. Komentarz, red. H. Dzwonkowski, Warszawa 2016.

Szymańska U., Zacher Z., Opłata produktowa w ochronie środowiska przed odpadami opakowaniowymi, „Ochrona Środowiska. Przegląd” 2004, nr 4.

Teszner K., Komentarz do art. 13, [w:] Ordynacja podatkowa. Komentarz, red. L. Etel, Warszawa 2017.

\title{
Province Marshal as a tax authority
}

\author{
Summary
}

The Province Marshal (voivodeship marshal) does not hold the status of an authority in local government units. The Province Marshal serves only as the chairman of the province government, that is, the executive body of the local government of the province. From the perspective of the law on public levies, and in particular the law regulating the size and collection of public levies, the Province Marshal is a tax authority or at least a body which has the authority of a tax authority. As a result of introducing further public dues into the Polish system of public levies, in particular dues related to activities that have negative environmental impact, the scope of the Province Marshal's role in assessing and levying of such dues has become more significant. The role of a Province Marshal is not limited only to the assessment and collection procedures, but also to other tasks, such as gathering of information, keeping of records and drawing up of reports.

Keywords: local government, Province Marshal, tax authority, charges, product charges. 